\title{
Evaluation of the role of ATP-binding cassette transporters as a defence mechanism against temephos in populations of Aedes aegypti
}

\author{
Estelita Pereira Lima ${ }^{1,2}{ }^{+}$, Marília Oliveira Fonseca Goulart ${ }^{3}$, Modesto Leite Rolim Neto ${ }^{1,2}$ \\ ${ }^{1}$ Faculdade de Medicina, Universidade Federal do Cariri, Barbalha, CE, Brasil Faculdade de Medicina do ABC, Santo André, SP, Brasil \\ ${ }^{3}$ Instituto de Química e Biotecnologia, Universidade Federal de Alagoas, Maceió, AL, Brasil
}

The role of ATP-binding cassette (ABC) transporters in the efflux of the insecticide, temephos, was assessed in the larvae of Aedes aegypti. Bioassays were conducted using mosquito populations that were either susceptible or resistant to temephos by exposure to insecticide alone or in combination with sublethal doses of the ABC transporter inhibitor, verapamil $(30,35$ and $40 \mu \mathrm{M})$. The best result in the series was obtained with the addition of verapamil $(40 \mu M)$, which led to a $2 x$ increase in the toxicity of temephos, suggesting that ABC transporters may be partially involved in conferring resistance to the populations evaluated.

Key-words: Aedes aegypti - ABC transporters - resistance mechanisms

In the absence of vaccines or specific drug treatments for most arthropod-borne diseases such as dengue, vector control, through the use of insecticides, is one of the main strategies to prevent or contain disease outbreaks. However, its indiscriminate use, which can lead to the dissemination of resistance in the field, poses one of the greatest challenges with regard to vector control strategies (Melo-Santos et al. 2010). Due to the limited arsenal of effective insecticides and the low chances for new compounds to reach the market (OPAS/OMS 2008), it becomes necessary to adopt strategies that optimise the use of these products while managing insecticide resistance (Strode et al. 2012).

Studies aimed at identifying the mechanisms and molecular basis of resistance are paramount to enable efficient vector control. According to Strode et al. (2012), metabolic resistance is one of the main mechanisms used by insects. It is achieved either by the super-expression of detoxifying enzymes or by alterations in their amino acid sequences which confer higher metabolic efficiency.

Three major enzymatic systems are involved in the detoxification of organochlorines, organophosphates (OPs), carbamates and pyrethroids (Hemingway \& Ranson 2000, Braga \& Valle 2007). The most important detoxifying enzymes are esterases, glutathione S-transferases (GST) and monooxygenases (Hemingway et al. 2004, Grisales et al. 2013). Recent studies have shown a possible cellular defence mechanism that is not associated with the metabolic conversion of toxic compounds (Aurade et al. 2006, Porretta et al. 2008, Figueira-Mansur et al. 2013, Dermauw \& Van Leeuwen 2014), but is instead related

doi: 10.1590/0074-0276140164

Financial support: CNPq, CAPES, FAPEAL, RENORBIO, FMABC

+ Corresponding author: estelitaplima@hotmail.com

Received 12 May 2014

Accepted 1 October 2014 to the action of ATP-binding cassette $(\mathrm{ABC})$ transporters that act as ATP-dependent efflux pumps for transporting drugs and xenobiotics outside the cells, thereby decreasing their intracellular concentration (Chang 2003, Porretta et al. 2008, Azeredo et al. 2009, Huber et al. 2010). Among these transporters, the glycoproteins (P-gps) are the most studied for multidrug resistance (MDR) both in vitro and in vivo (Huber et al. 2010).

Due to their substrate structural analogy, chemical modulators can be used to reverse MDR. Verapamil, a calcium channel blocker, is also known as a modulator of P-gps and competes with cytotoxic compounds that act on the efflux pumps in the membrane (Lage 2003, Thomas \& Coley 2003, Higgins 2007, Donmez et al. 2011).

At the end of the 90s, the first cases of Aedes aegypti resistance to temephos in Brazilian populations were reported (Macoris et al. 1999). Currently, this phenomenon occurs in almost all Brazilian states. In the state of Ceará (CE), populations have shown moderate to high levels of resistance. Two of these populations, from Juazeiro do Norte and Barbalha, with resistance ratios $\left(\mathrm{RR}_{95}\right)$ of 7.2 and 30, respectively, were selected for the current study. The population from Barbalha also showed cypermethrin resistance, while the one from Juazeiro do Norte only showed a change in susceptibility.

Biochemical tests indicated that among the detoxification enzymes tested, only the activities of esterases and GSTs were altered in these populations when compared to the Rockefeller strain; moreover, there was also molecular evidence that a Kdr Ile1011Met mutation was involved in resistance toward cypermethrin (Lima et al. 2011).

Possible alternative defence mechanisms, such as the involvement of ABC transporters, has already been reported in Culex pipiens (L.), Aedes caspius and more recently in Ae. aegypti (Buss et al. 2002, Porretta et al. 2008, Bariami et al. 2012, Figueira-Mansur et al. 2013). Therefore, by using verapamil to inhibit protein activity, we herein investigated the role of these transporters in the detoxification of insecticides and in the resistance of $A e$. aegypti to temephos. Despite recent reports (FigueiraMansur et al. 2013), additional studies that use different 
TABLE

Lethal concentration $\left(\mathrm{LC}_{50}\right)$ and confidence interval $(95 \% \mathrm{CI})$ of temephos alone and associated with three concentrations of verapamil in Aedes aegypti populations

\begin{tabular}{|c|c|c|c|c|c|}
\hline Populations & $(\mathrm{n})^{a}$ & $\begin{array}{l}\text { Verapamil } \\
\qquad(\mu \mathrm{M})\end{array}$ & $\begin{array}{c}\text { Temephos } \mathrm{LC}_{50} \\
(\mathrm{mg} / \mathrm{L})(95 \% \mathrm{CI}) \\
\text { chi-square (p-value) }\end{array}$ & $\begin{array}{c}\text { Temephos } \mathrm{LC}_{50}(\mathrm{mg} / \mathrm{L})+ \\
\text { verapamil }(\mu \mathrm{M})(95 \% \mathrm{CI}) \\
\text { chi-square }(\mathrm{p} \text {-value })\end{array}$ & $\begin{array}{l}\text { Synergy } \\
\text { factor }\end{array}$ \\
\hline \multirow[t]{3}{*}{ Rockefeller $^{b}$} & 300 & 30 & $\begin{array}{c}0.010(0.009-0.011) \\
0.366(0.545)\end{array}$ & $\begin{array}{c}0.007(0.006-0.008) \\
2.612(0.271)\end{array}$ & 1.42 \\
\hline & 300 & 35 & $\begin{array}{c}0.009(0.007-0.010) \\
0.374(0.829)\end{array}$ & $\begin{array}{c}0.007(0.006-0.007) \\
0.004(0.951)\end{array}$ & 1.28 \\
\hline & 300 & 40 & $\begin{array}{c}0.012(0.009-0.046) \\
1.567(0.211)\end{array}$ & $\begin{array}{c}0.006(0.006-0.007) \\
0.016(0.900)\end{array}$ & 2.00 \\
\hline $\begin{array}{l}\text { Juazeiro } \\
\text { do Norte }\end{array}$ & 300 & 40 & $\begin{array}{c}0.029(0.027-0.032) \\
1.297(0.523)\end{array}$ & $\begin{array}{c}0.020(0.011-0.027) \\
0.515(0.473)\end{array}$ & 1.45 \\
\hline Barbalha & 300 & 40 & $\begin{array}{l}0.175(0.132-0.334) \\
0.079(0.777)\end{array}$ & $\begin{array}{c}0.090(0.788-0.109) \\
0.115(0.734)\end{array}$ & 1.94 \\
\hline
\end{tabular}

$a$ : larvae used in bioassays; $b$ : reference population.

field populations of both susceptible and resistant strains are welcome in order to reinforce our understanding of the role of these proteins in insecticide resistance.

Ae. aegypti eggs were collected in the field from Juazeiro do Norte ( $\left.7^{\circ} 12^{\prime} 47^{\prime \prime} 39^{\circ} 18^{\prime} 55^{\prime \prime}\right)$ and Barbalha ( $\left.7^{\circ} 18^{\prime} 40^{\prime \prime} 39^{\circ} 18^{\prime} 15^{\prime \prime}\right)$ by using 100 oviposition traps (ovitraps) distributed homogeneously in each area, based on the recommendations of the MoReNAa network (Lima et al. 2003, Montella et al. 2007). These two areas are located in the southern region of CE, more than $500 \mathrm{~km}$ away from the capital and equidistant by approximately $10 \mathrm{~km}$. These populations of mosquitoes have been shown to be resistant to temephos (Lima et al. 2011). More than 50\% of the ovitraps were positive for Aedes spp eggs. Field derived colonies from each selected population were established with approximately 2,000 mosquitoes (males and females) from the collected eggs. Populations were kept under controlled conditions in the insectary of the Federal University of Ceará (UFCE) (Cariri Campus), in order to obtain the filial generation (F1), which was utilised in the experiments described below. The Rockefeller strain, the standard strain for insecticide susceptibility tests, was obtained from a sub-strain kindly provided by Aggeu Magalhães Research Centre, Oswaldo Cruz Foundation, Recife, state of Pernambuco, and was used in all experiments as a susceptible reference strain.

Temephos (Pestanal 97.5\%, Sigma-Aldrich), an OP larvicide and verapamil (Sigma-Aldrich, V4629-1G, lot $048 \mathrm{k} 1343)$ were used without further treatment. The dose-response trials followed the methodology proposed by the World Health Organization (WHO 1981) and were performed in the Laboratory of Entomology at the Cariri School of Medicine, UFC, Barbalha, CE. Lots of 20 third-instar larvae placed in glasses with 250 $\mathrm{mL}$ of water, treated with either temephos or temephos in combination with verapamil, were employed. As controls, additional groups of larvae were treated either with water and ethanol or only with verapamil.
The tests were conducted using, on average, six concentrations of temephos in triplicates. The readings were taken $24 \mathrm{~h}$ after exposure with temperature monitoring $\left(25 \pm 2{ }^{\circ} \mathrm{C}\right)$. The sublethal dose of verapamil $(30 \mu \mathrm{M})$ used in the bioassays was evaluated by treating larvae with five concentrations of verapamil $(10 \mu \mathrm{M}-50 \mu \mathrm{M})$ according to the protocol described previously. Exposure to these concentrations of verapamil alone did not cause any mortality in the larvae, as was observed in the control group treated with water and ethanol (data not shown). All tests were repeated three times for each population (field and Rockefeller).

Data analysis was performed using the SPSS program (v.8.0) by log-probit regression analysis. After this analysis, the synergy factor (SF) was calculated from the ratio between the lethal concentration $\left(\mathrm{LC}_{50}\right)$ value obtained with the insecticide treatment alone and the $\mathrm{LC}_{50}$ obtained with the insecticide + verapamil.

The obtained results are listed in Table. In the Rockefeller population that was susceptible to temephos, a comparison of $\mathrm{LC}_{50}$ values from assays with temephos alone and in combination with three concentrations of verapamil showed that the addition of verapamil at the lower concentration $(30 \mu \mathrm{M})$, increased the toxicity of the insecticide to 1.42 , while the higher concentration $(40 \mu \mathrm{M})$ increased the toxicity of the insecticide by $2 \mathrm{x}(\mathrm{SF}=2)$. This increased toxicity of temephos in Ae. aegypti following verapamil addition suggests that ABC transporters participate in the OP mode of action, confirming the data previously reported by FigueiraMansur et al. (2013). For the resistant populations (Lima et al. 2011), data (Table) were shown only for the higher concentration of verapamil $(40 \mu \mathrm{M})$ because lower concentrations (30 and $35 \mu \mathrm{M})$ did not provoke any significant increase in mortality.

Despite a higher SF (3.5) value, similar results were obtained by Porretta et al. (2008) in Ae. caspius. However, the replacement of temephos by diflubenzuron made 
this insecticide 16.4 times more toxic, confirming the action of P-gps in the same efflux process. The authors believe that the difference in the role of P-gps observed between diflubenzuron and temephos may be due to the modes of action of these insecticides. Temephos is more readily absorbed by contact and acts directly on the central nervous system, while diflubenzuron is absorbed mainly by ingestion and interferes with chitin synthesis by the insect. In some insects, P-gp is abundant in the gut and in the Malpighian tubules, which may explain the greater inhibition of protein activity in the digestive system of the mosquito.

In summary, the results of this study provide additional evidence on the contribution of $\mathrm{ABC}$ transporters to temephos resistance in Ae. aegypti populations of CE, which complements the resistance mechanisms associated with esterases and GSTs that have previously been reported by Lima et al. (2011).

\section{REFERENCES}

Aurade R, Jayalakshmi SK, Sreeramulu K 2006. Stimulatory effect of insecticides on partially purified P-glycoprotein ATPase from the resistant pest Helicoverpa armigera. Biochem Cell Biol 84: 1045-1050.

Azeredo FJ, Uchôa FT, Costa TD 2009. Papel da glicoproteína-P na farmacocinética e nas interações medicamentosas. Rev Bras Farm 90: 321-326.

Bariami V, Jones CM, Poupardin R, Vontas J, Ranson H 2012. Gene amplification, $\mathrm{ABC}$ transporters and cytochrome P450s: unraveling the molecular basis of pyrethroid resistance in the dengue vector, Aedes aegypti. PLoS Negl Trop Dis 6: e1692.

Braga IA, Valle D 2007. Aedes aegypti: history of control in Brazil. Epidemiol Serv Saude 16: 113-118.

Buss DS, McCaffery AR, Callaghan A 2002. Evidence for p-glycoprotein modification of insecticide toxicity in mosquitoes of the Culex pipiens complex. Med Vet Entomol 16: 218-222.

Chang G 2003. Multidrug resistance ABC transporters. FEBS letters 555: 102-105.

Dermauw W, Van Leeuwen T 2014. The ABC gene family in arthropods: comparative genomics and role in insecticide transport and resistance. Insect Biochem Mol Biol 45: 89-110.

Donmez Y, Akhmetova L, Iseri OD, Kars MD, Gunduz U 2011. Effect MDR modulators verapamil and promethazine on gene expression levels of MDR1 and MRP1 in doxorubicin-resistant MCF-7 cells. Cancer Chemother Pharmacol 67: 823-828.

Figueira-Mansur J, Ferreira-Pereira A, Mansur JF, Franco TA, A1varenga ESL, Sorgine MHF, Neves BC, Melo ACA, Leal WS, Masuda H, Moreira MF 2013. Silencing of P-glycoprotein increases mortality in temephos-treated Aedes aegypti larvae. Insect Biochem Mol Biol 22: 648-658.

Grisales N, Poupardin R, Gomez S, Fonseca-Gonzales I, Ranson H, Lenhart A 2013. Temephos resistance in Aedes aegypti in Colombia compromises dengue vector control. PLoS Negl Trop Dis 7: e2438.
Hemingway J, Hawkes NJ, McCarroll L, Ranson H 2004. The molecular basis of insecticide resistance in mosquitoes. Insect Biochem Mol Biol 34: 653-665.

Hemingway J, Ranson H 2000. Insecticide resistance in insect vectors of human disease. Annu Rev Entomol 45: 371-391.

Higgins CF 2007. Multiple molecular mechanisms for multidrug resistance transporters. Nature 446: 749-757.

Huber PC, Maruiama CH, Almeida WP 2010. Glicoproteína-P, resistência a múltiplas drogas (mdr) e relação estrutura-atividade de moduladores. Quim Nova 33: 2148-2154.

Lage H 2003. ABC-transporters: implications on drug resistance from microorganisms to human cancers. Int J Antimicrob Agents 22: 188-199.

Lima EP, Paiva MH, de Araújo AP, da Silva EV, da Silva UM, de Oliveira LN, Santana AEG, Barbosa CN, Paiva Neto CC, Goulart MOF, Wilding CS, Ayres CFJ, Melo-Santos MAV 2011. Insecticide resistance in Aedes aegypti populations from Ceará, Brazil. Parasit Vectors 4: 2-12.

Lima JB, Da-Cunha MP, da Silva RC, Galardo AK, Soares SS, Braga IA, Ramos RP, Valle D 2003. Resistance of Aedes aegypti to organophosphates in several municipalities in the state of Rio de Janeiro and Espírito Santo, Brazil. Am J Trop Med Hyg 68: 329-333.

Macoris MLG, Andrighetti MT, Takaku L, Glasser CM, Garbeloto VC, Cirino VCB 1999. Alteração de resposta de suscetibilidade de Aedes aegypti a inseticidas organofosforados em municípios do estado de São Paulo, Brasil. Rev Saude Publica 33: 521-522.

Melo-Santos MAV, Varjal-Melo JJ, Araújo AP, Gomes TCS, Paiva MH, Regis LN, Furtado AF, Magalhães T, Macoris MLG, Andrighetti MTM, Ayres CFJ 2010. Resistance to the organophosphate temephos: mechanisms, evolution and reversion in an Aedes aegypti laboratory strain from Brazil. Acta Trop 113: 180-189.

Montella IR, Martins AJ, Viana-Medeiros PF, Lima JB, Braga IA, Valle D 2007. Insecticide resistance mechanisms of Brazilian Aedes aegypti populations from 2001 to 2004. Am J Trop Med Hyg 77: 467-477.

OPAS/OMS - Organização Pan-Americana da Saúde/Organização Mundial da Saúde 2008. Controle integrado de vetores: resposta integral às doenças transmitidas por vetores, OPAS/OMS/ CD48/13, Washington, $12 \mathrm{pp}$.

Porretta D, Gargani M, Bellini R, Medici A, Punelli F, Urbanelli S 2008. Defense mechanisms against insecticides temephos and diflubenzuron in the mosquito Aedes caspius: the P-glycoprotein efflux pumps. Med Vet Entomol 22: 48-54.

Strode C, Melo-Santos M, Magalhães T, Araújo A, Ayres C 2012. Expression profile of genes during resistance reversal in a temephos selected strain of the dengue vector, Aedes aegypti. PLoS ONE 7: e39439.

Thomas H, Coley HM 2003. Overcoming multidrug resistance in cancer: an update on the clinical strategy of inhibiting P-glycoprotein. Cancer Control 10: 159-165.

WHO - World Health Organization 1981. Instructions for determining the susceptibility or resistance of mosquito larvae to insecticides, $\mathrm{WHO} / \mathrm{VBC} / 81.807$, Geneva, $6 \mathrm{pp}$. 